\section{National curriculum}

SIR-Your leading article (Nature 328 , $356 ; 1987)$ on the British government's proposal for a national curriculum, in primary schools as well as secondary schools, failed to address all the many difficulties in the proposal.

While a set curriculum in all schools might be advantageous to the small mobile fraction of the school population (usually the children of the upper echelons of management) most children within an educational authority are static.

The attainment tests at 7,11,14 and 16 years. proposed but not yet defined, are fraught with difficulties. The young are not uniform sponges that can imbibe a given amount of water and release it on being squeezed, but form a mixed population with a wide distribution of ability and rate of educational development. To set a national 'norm' for attainment will divide the school population into two classes those above the 'norm' (pass) and those below (fail). And would the evaluation of the norm' include the fraction of the school population at present considered 'educationally subnormal'?

Much has been written about the beneficial effects of parental involvement and encouragement and the home environment (availability of books) on a child's academic attainment. This government's contention that teachers are responsible for "diminished expectations in young people" is not necessarily correct because the home environment does determine, to a large extent, a young person's expectations. Poverty, because of low (or no) income and poor job prospects, despite educational success, is bound to influence adversely a young person's expectations and induce a feeling of hopelessness which no amount of 'teaching' could overcome.

So is it valid to compare teaching in schools that draw from different catchment areas on the basis of their attainment rates? In multistream schools, will teachers of the 'high flyers' be rewarded while the teacher of the 'backward class' stays bottom of the salary scale?

Teaching towards so many attainment tests, if success/failure is to be taken as a measure of teaching ability, is guaranteed to stultify education and reduce it simply to 'learning by rote'.

Finally, your comments about Welsh suggest that you have little appreciation or knowledge of the language or the people. The Welsh have a cultural background at least equal to and which predates 'English'. If the British government were to observe EEC directives, it should actively encourage the preservation of the Welsh language and culture in the principality.

Iolo ab Ithel Davies Department of Pharmacy,

Queen's University,

97 Lisburn Road, Belfast BT9 7BL, UK \section{Plymouth brethren}

SIR-Contrary to your report (Nature $\mathbf{3 2 9}$, $96 ; 1987)$ on the proposed merger between the two marine laboratories in Plymouth, the Laboratory of the Marine Biological Association and the NERC Institute for Marine Environmental Research, it is not a "stated goal" of this proposal that the merger should effect "cost savings". The stated goals, to quote from the draft Agreement, are "to formalize the collaboration between the two laboratories", "to harness their scientific strengths and reputations into one centre of excellence" and "to safeguard the future of research and related activities in Plymouth"

These objectives are primarily scientific and designed to enhance the research in Plymouth at a time of considerable scientific challenge in the marine sciences which demand closer collaboration and interdependence between the traditional disciplines of physical, chemical and biological oceanography.

Neither partner in this merger is unaware of the financial difficulties facing the marine sciences within NERC and elsewhere; we face these difficulties whether as one laboratory or two. But we also wish to respond to the longer-term scientific challenge, by merging our experience, our expertise and our enthusiasm. The true motives for the merger are to be found here, not in response to the immediate and, we hope, transient financial climate.

BRIAN L. BAYNE (Director)

Institute for Marine Environmental Research,

Prospect Place, The Hoe, Plymouth PLI 3DH, UK

\section{Yeast the model}

SiR-Anne McLaren (Nature 328, 10; 1987) appears to have a very personal bias against the word 'embryo', despite its ancient origins and readily translatable meaning (the growing human, in this case), to describe the product of the union of male and female gametes. Her failure to see any significance in the unicellular human embryo may be blinding her to the reality present and to the significance of the 'kingdom' of unicellular organisms. As E.B. Wilson has indicated: "Long ago it became evident that the key to every biological problem must finally be sought in the cell, for every living organism is, or at some time has been, a cell"'.

It is now almost 30 years since the basic animal research work of 'in-vitro fertilization' (IVF) was completed and 25 years since the first attempts at human $\mathrm{IVF}^{2}$. Despite the great promises of spin-off from IVF research into the field of genetic diseases, no therapies have become available.

But Ira Herskowitz, geneticist and a recent recipient of a MacArthur Fellowship (see Nature 327, 680; 1987), has indicated that a unicellular organism, Saccharomyces cerevesiae, could be the most important model for answering the big questions of cellular biology: "If you want to understand a process at the molecular level, the best - and in some cases the only — place to start with is yeast"'.

The sooner Anne McLaren and others get off the unethical 'bandwagon' of human embryo research and onto the ethically suitable model of yeast research, the sooner will the biological problems of infertility and genetic diseases be solved.

Neath General Hospital, Patrick W. Gill.

Neath, Glamorgan SAII $2 L Q, U K$

Wilson E. B. The Cell in Development and Heredity 3rd edn (Macmillan, New York, 1925)

. Biggers J.D New Engl. J. Med. 304, 336-342 (1981). 3. Discover $71-83$ (November, 1986).

\section{Schrödinger v. Marx}

SIR-M.F. Perutz, in his evaluation ${ }^{1}$ (or devaluation, to be precise) of Schrödinger's What is Life $?^{2}$ has committed the classical error of the description of an elephant by three blind men. Each of his statements is scientifically correct but, alas, the summation is wildly off-target. The analysis of what is wrong in What is Life? is surely of historico-scientific value, but then to denigrate the great book as a scientific advertisement of Timoféeff, Zimmer and Delbrück's paper ${ }^{3}$ is a bit too preposterous.

So far as science is concerned, the concepts of open systems and irreversible thermodynamics, to name but two, have derived from this little book. But surely, when one judges the merit of a book decades after its publication, what matters should be the role played by the book in the growth of subject that the book originally dealt with. In that respect, What is Life? has stood the test of time by being the grand initiator of the present integrated view of physics and biology.

It is interesting to compare What is Life? with Darwin's Origin of Species and Marx's Das Kapital. To judge from the present knowledge of molecular biology (as espoused by Kimura in his Neutral Theory of Evolution ${ }^{4}$ and the economic and political conduct of socialist countries (à la glasnost and perestroika), both books would no doubt be found "highly erroneous", but this judgement would not prevent them from being among the greatest books ever written.

Santanu Datta

Department of Clinical Genetics,

Karolinska Institute,

Stockholm, Sweden

. Perutz, M.F. Nature 326, 555-558 (1987)

Schrodinger, E. What is Life? (Cambridge University Press, 1946)

Timoféeff-Ressovsky, N.W. Zimmer, K.G. \& Delbrück, M. Nachrichten auf der Biologie der Gesellschaft der Wissen. schaften Göttingen 1. 189-245 (1935).

4. Kimura, M. The Netutral Theory of Molecular Evolution (Cambridge University Press, 1983) 